\title{
Competitiveness of Regions in the Visegrad Group Countries
}

\author{
Eva Koisova, Eva Grmanova, Katarina Skrovankova, Julia Kostrova
}

\author{
Alexander Dubcek University of Trencin \\ Studentska 2, 91101 Trencin \\ E-mail.eva.koisova@tnuni.sk,eva.grmanova@tnuni.sk,katarina.skrovankova@tnuni.sk,julia.kostrova@tnuni.sk \\ cross $^{\text {ref }}$ http://dx.doi.org/10.5755/j01.ee.30.2.21746
}

\begin{abstract}
At present, the competitiveness of regions plays a significant role in regional development. Competitiveness is the key to the ability of regions to ensure high level of income for their residents. In order to increase the competitiveness of regions, factors driving competitiveness need to be supported. The primary objective of the paper is to contribute to the body of knowledge on regional competitiveness disparities in the regions of the Visegrad Four (V4) nations. Moreover, the authors seek to offer to offer a new, both theoretical and practical, approach to evaluating regional efficiency and competitiveness. In addition, two secondary objectives were set. The first objective is to identify the most competitive regions in the Visegrad Group. The second objective is to find whether there is a correlation between the two approaches chosen. The paper uses data envelopment analysis models (DEA) are used in order to evaluate the competitiveness of the regions. DEA models evaluate the efficiency with which states and regions can transform inputs into outputs. Thus, DEA models assess how large outputs the states or regions can achieve in spending a unitary amount of inputs (sources). Tobit regression method is used to identify regression relationships. Regional disparities are analysed at NUTS 2 level. The Bratislava region seems to be the most competitive region in the Visegrad countries as it follows from DEA models analysis.

The practical importance of assessing regional competitiveness with a less traditional method of DEA models lies in the adjustment of basic inputs, such as the number of persons with tertiary education, employment rate and research expenditure.
\end{abstract}

Keywords: Competitiveness; Data Envelopment Analysis; Tobit Regression model; regions; Visegrad Group Countries.

\section{Introduction}

Political and economic changes in the late 1980's brought about significant changes in the territorial structure of post-socialist countries. They led to improvements in macroeconomic indicators and social and economic development. The conditions for development have improved in these countries and many transforming countries are seeing high economic growth rate. The primary goal of achieving high economic growth rate has towered above other goals, such as social equality, and economic and territorial cohesion. As a result, the increase in regional disparities have occurred (Torok, 2017). Economic policies of the European Union aim to enhance competitiveness in the global market. (Ivanova, Kordos \& Habanik, 2015). The European Commission defines competitiveness as the ability to generate relatively high income and employment levels while exposed to international competition. Recently, the definition has been added the notions of quality of life and sustainable development. In the most general sense, competitiveness may be defined as the capability of a country, measured by comparison with other countries, to shape and ensure an economic, social and political environment able to support the accelerated and durable value-added creation (Mereuta et al., 2007).

The concept of regional competitiveness relies on two distinct and contradictory economic categories that predict productivity and employment growth (Lengyel \& Rechnitzer, 2013).

It is quite difficult to assess competitiveness at macroeconomic or regional level. Viturka (2007) argues that long-term decline in either national or regional competitiveness leads "only" to a correspondingly lower standard of living of their population.

Many new strategies and development plans, and funding options have been developed and are being developed that seek to establish processes and different procedures to mitigate regional disparities and promote lagging regions. Despite the efforts, disparities have not been reduced and many authors maintain that disparities across regions keep rising (Dachin, 2008, Goschin et al., 2008; Boldea et al., 2012).

Indicators which are to serve as the sources of information in assessing and analysing environmental, social, and economic processes, have been worked up. They are to reduce dissonances between social awareness and behaviour. Moreover, they are to coordinate decision-making processes in the light of better application of sustainability principles. (Bauler, 2002)

The primary objective of the paper is to contribute to the body of knowledge on regional competitiveness disparities in the regions of the Visegrad Four (V4) nations. Moreover, the paper attempts to offer a new, both theoretical and practical, approach to evaluating regional efficiency and competitiveness. Also, two secondary objectives were set in the paper. The first objective was to identify the most competitive regions in the Visegrad Group. The findings can be beneficial for less competitive regions to learn from their better performing counterparts.

Since there are several approaches to assessing competitiveness, the second objective was to find whether there is a correlation between the two approaches chosen.

In order to evaluate regional competitiveness within the European Union, NUTS 2 level is used. The European 
Commission places considerable emphasis on NUTS 2 territorial units in terms of attaining the objectives of the EU Cohesion Policy (Stanickova \& Skokan, 2012). Because of that fact, the subject of our analysis are regions NUTS2 in V4 countries. The Czech Republic is divided into 8 NUTS2 regions, Hungary to 7 NUTS2 regions, Poland to 16 NUTS2 regions and Slovakia to 4 NUTS2 regions. Those positioned around the capital cities are of great significance. They are Prague in the Czech Republic, Warsaw in the Mazowieckie region and Budapest in Kozep-Magyarorszag region. The capital city of Slovakia is located in the Bratislava region.

\section{Theoretical Background}

The concept of competitiveness is defined differently by many authors.

Nowadays, competitiveness is the key driver of economic growth. Malakauskaite and Navickas (2010) define competitiveness as a country's ability to successfully operate and effectively compete in international markets, at the same time maintaining a high quality of life and well-being of its citizens.

The economic development of today makes EU countries focus on qualitative factors in order to increase their competitiveness, (Kordos, 2016). According to the OECD (2018), states must become "more competitive" if they are to maintain their economic position vis-à-vis other industrialized or developing countries. Competitiveness is subject to analysis and comparison to various entities. There include businesses, institutions, organizations or regions. There is no clear-cut definition of the concept of competitiveness in general and of the competitiveness of regions. The European Commission (2013) shares the understanding of regional competitiveness, defined as the ability to offer an attractive and sustainable environment for firms and residents to live and work (Dijkstra et al., 2011). Annoni and Dijkstra (2013) state that for politicians and policymakers, it offers a fairly fuzzy umbrella concept that covers aspects that matter to the firms and residents of a region. It tends to focus on measurable differences between regions, which fall (partly) under the control of public authorities, without employing any clear political or conceptual framework.

The definition needs to cover the regional aspect of competitiveness (Ivanova \& Masarova, 2017). Malakauskaite and Navickas (2011) view competitiveness as the capability of regions to secure their economic growth. The assessment of competitiveness is a complex multi-stage process, in which several quantitative and qualitative factors are considered in order to determine the ability of regions to gain and maintain a competitive advantage.

Competitive advantages are attributable to a variety of factors, including demographic development, labour productivity, GDP, employment rate and many others.

Last time the assessment of the competitiveness of different territorial entities have become an up-to-date problem (Gabdrakhmanov \& Rozhko, 2014). Competitiveness of regions manifests itself in a variety of aspects. The advantage of regions can be, for example, in terms tourism sector competitiveness factors, entrepreneurial activity (Audretsch \& Pena-Legazkue, 2012), logistics systems and infrastructure, or the demographic profile of the region (Poot, 2008).
National competitiveness relies on the competitiveness of regions. Enhancing regional competitiveness requires the ability to execute innovation policy objectives in the context of national or regional innovation systems. A competitive region is one that is able to attract and retain successful businesses and maintain or raise the standard of living for the population in the region (OECD, 2018). In order to increase the competitiveness of regions, it is necessary to back up the factors, which increase competitiveness. At the same time, it is necessary to monitor their development in other countries or regions. Competitiveness within regions relies on the competitiveness development of other regions. Thus, it refers to a relative factor that is determined by the developments in other regions. Stanickova (2014) notes that regional competitiveness is conditioned by the regionalization of public policy due to shifting of decision-making to and coordination of activities at the regional level.

There are several approaches to assessing and comparing competitiveness. They mostly use composite economic indicators and their comparison. It follows that they do not look at one, but several indicators, which may have different representation and weight. The usage of different indicators, while taking into account different aspects, can lead to different assessment results and conclusions. Over the last decades, various statistical indicators have been developed that are able to generalize the aggregative coefficient taking into account a number of factors that influence the development of regions (Mashokhida et al., 2018). For instance, Komarova (2007) developed a system of indicators to calculate the region's integrated competitiveness level. The system includes three components, such as the accessibility and efficiency of regional sources utilization, living standards of the people in the region, and investments attractiveness and activities in the region. In order to assess social and economic development, Granberg et al. (2000) used a methodology, which contains basic indicators for nine assessment units. Andreev et al. (2008) developed a comprehensive system of indicators, comprising a set of key and secondary indicators. The sets of indicators describe the development of the social, economic and environmental spheres of a region.

According to Žitek and Klimova (2015), the European Union measures the competitiveness of regions using the Regional Competitiveness Index (RCI). RCI is based on the methodology developed by the World Economic Forum. The indicators are followed within 11 pillars that describe both inputs and outputs of territorial competitiveness. The 11 pillars are grouped into three sub-indices, which are basic (five pillars), efficiency (three pillars), and innovative (three pillars) factors of competitiveness.

\section{Data and Methodology}

The paper attempts to assess the competitiveness of regions based on technical efficiency in DEA models. The description of models, used to calculate the technical efficiency score, is in the methodology section of the paper.

We compared the evaluation of the competitiveness of regions based on the use of DEA models with the RCI values. Next, the correlation between the technical efficiency and RCI scores was analysed. In order to analyse the correlation relationship, Tobit regression was utilised. 
Inputs and outputs in DEA models were chosen according to approaches by some authors who did considerable work on regional competitiveness.

In accordance to Stanickova and Melecky (2012), two output indicators were considered important, such as GDP and labour productivity.

Regional GDP is one of the most important macroeconomic indicators. Regional GDP is used to compare the efficiency of the economy in individual regions. GDP per capita is the most widely-used measure of the standard of living. Labour productivity has also influence on standard of living. High productivity decreases expenses and increases profit.

Considering inputs, three indicators are important. The employment rate is crucial for both the economy and social estimates. Economic efficiency is determined by employment rate, support of science and research, and other factors. Competitiveness of today is the result of the support of science and research in the past. Last, but not least, education is important. A high ratio of employees with a good quality post-graduate education leads to an increase in innovation and work productivity.

Three input indicators and two output indicators were selected.

The inputs in DEA models were:

- employment rate in \%,

- research expenditure in EUR per inhabitant,

- number of persons with tertiary education (thousands).

The outputs in DEA models were:

- GDP Purchasing Power Standard (PPS) per inhabitant,

- labour productivity.

Calculation of labour productivity:

$\mathrm{PP}=\mathrm{GDP} /$ number of employees .

The data for inputs and outputs were drawn from Eurostat (2014, 1, 2, 3, 4). Inputs, outputs, and Eurostat data sources are shown in Table 1. The RCI data were used from the Eurostat Regional Yearbook (2014). The period under analysis was the year 2014 .

Table 1

Sources of Used Databases and Data

\begin{tabular}{|l|l|l|}
\hline 1 input & the number of persons with tertiary education in thousands & hrst_st_rcat \\
\hline 2 input & employment rate in \% & lfst_r_lfe2emprt \\
\hline 3 input & $\begin{array}{l}\text { research expenditure in EUR } \\
\text { per inhabitant }\end{array}$ & rd_e_gerdreg \\
\hline 1 output & GHD Purchasing power standard (PPS) per inhabitant & nama_10r_2gdp \\
\hline 2 output & labour productivity & nama_10r_2gdp; [lfst_r_lfe2emp] \\
\hline
\end{tabular}

\section{Methodology}

DEA Dodels

According to Stanickova and Melecky (2012) the DEA models evaluate the efficiency of which states and regions can transform inputs into outputs. Thus, DEA models assess how large outputs the states or regions can achieve by spending a unitary amount of inputs (sources). This very nature of DEA models makes it possible to consider the efficiency of states and regions as a kind of "mirror" of competitiveness. When applying DEA models, it is assumed that the higher the level of development and performance of state and regions, the higher their level of technical efficiency and thus the higher competitive potential of states or regions.

DEA models are based on linear programming. Efficiency is assessed by the measure of technical efficiency (efficiency score) being calculated for each subject under analysis. Efficiency score is dependent on the value of indicators divided into inputs and outputs.

There are several different DEA models. Basic DEA models include CCR models and BCC models. CCR models follow from the assumption of constant returns to scale. BCC models are based on the assumption of variable returns to scale. They can be focused on inputs and outputs. For CCR and BCC input-oriented models, the efficiency score $\theta_{q}$ has the internal value $\langle 0 ; 1\rangle$.

When assessing efficiency score, an efficiency frontier is important. Objects lying on it (efficient objects) have an efficiency score equal to one. Objects not lying on the efficiency frontier have the efficiency score calculated relative to the efficiency frontier. The more distant from the efficiency frontier, the lesser the technical efficiency scale is.

Assuming, that we have $n$ homogenous objects $U_{l}$ to $U_{n}$ and that we observe $m$ inputs and $r$ outputs, the efficiency score $\theta_{q}$ in the BCC model is the solution of the linear programming task

$$
\begin{array}{r}
\text { minimize } z=\theta_{q}-\varepsilon\left(\mathbf{e}^{T} \mathbf{s}^{*}+\mathbf{e}^{T} \mathbf{s}^{-}\right), \\
\text {under conditions } \mathbf{X} \lambda+\mathbf{s}^{-}=\theta_{q} \mathbf{x}_{q}, \\
\mathbf{Y} \lambda-\mathbf{s}^{+}=\mathbf{y}_{q}, \\
\mathbf{e}^{T} \lambda=1, \\
\lambda, \mathbf{s}^{+}, \mathbf{s}^{-} \geq 0,
\end{array}
$$

where $\theta_{q}$ expresses the efficiency score of subject $U_{q}$, $\mathbf{X}=\left\{x_{i j}, i=1, \ldots, m, j=1, \ldots, n\right\} \quad$ is the matrix of inputs, $\mathbf{Y}=\left\{y_{i j}, i=1, \ldots, r, j=1, \ldots, n\right\}$ is the matrix of outputs, $\mathbf{s}^{+}, \mathbf{s}^{-}$are deviational variables, $\boldsymbol{\lambda}$ is the matrix of weights, $\mathbf{e}^{T}=(1,1, \ldots, 1), \quad \varepsilon$ is the infinitesimal constant (Jablonsky, Dlouhy, 2004).

The CCR model differs from the BCC model by not having the convexity condition (4).

To assess and compare the efficient objects, superefficiency models were proposed. The most widely known and applied is the Andersen and Petersen's super- efficiency model. The rate calculated in the input-oriented model has a value bigger than 1 . Objects with the highest super-efficient score are regarded the best in the model. EMS program will be used to express efficiency scores.

\section{RCI}

According to the European Commission, RCI is a composite index evaluating different areas. They are classified into three groups: basic, efficiency, and innovation. The basic pillars in RCI include Quality of Institutions, Macroeconomic Stability, Infrastructure, Health and the 
Eva Koisova, Eva Grmanova, Katarina Skrovankova, Julia Kostrova. Competitiveness of Regions in the Visegrad...

Quality of Primary and Secondary Education. The efficiency pillars include Higher Education and Lifelong Learning, Labour Market Efficiency and Market Size. The innovation pillars include Technological Readiness, Business Sophistication, and Innovation. RCI values are published at three-year intervals $(2010,2013,2016)$.

\section{Tobit Model}

Due to the fact, that an efficiency score is a number from the interval $\langle 0 ; 1\rangle$, the Tobit model is necessary to be used for the regression of this dependent variable from the independent variable. It is also known as censored regression and belongs to the group of regression with the limited dependent variable.

According to Guneş, Yilmaz (2016) the standard Tobit model can be defined as follows for observation $y_{i}^{*}=\beta^{T} x_{i}+\varepsilon_{i}, \quad y_{i}=y_{i}^{*}$, if $y_{i}^{*} \geq 0$ and $y_{i}=0$, otherwise

$$
\varepsilon_{i} \sim N\left(0, \sigma^{2}\right)
$$

$x_{i}$ are explanatory variables,

$\beta$ are unknown parameters,

$y_{i}^{*}$ is a latent variable,

$y_{i}$ is the dependent variable.

We will use the Matrixer program to express the regression in Tobit models.

\section{Findings and Discussion}

\section{Brief Characteristics of Regions}

NUTS 2 regions of the V4 countries differ significantly in many aspects, e.g. demographics. It can be inferred from Eurostat data $(2014,5)$ that the Mazowieckie region and the Slaskie region are the most populated regions in Poland. The least populated region is the Bratislava region in Slovakia.

Most of the analysed regions had a negative natural change of population. The region of Lódzkie in Poland had the lowest natural change of population. The region of Lódzkie was followed by the Del-Alfold region in Hungary. The largest positive natural change of population was in the Wielkopolskie region in Poland. Most of the regions also had negative net migration. The largest decrease in net migration was recorded in the Slaskie region in Poland. Contrariwise, positive net migration was recorded in the Kozep-Magyarorszag region in Hungary. Only nine of all analysed regions had positive net migration as well as the natural change of population. They were the following regions: Severovychod (Northeast), Wielkopolskie, Jihovychod (Southeast), Pomorskie, Malopolskie, Bratislava region, Stredni Cechy (Central Bohemian region), Prague region and Mazowieckie region.

Based on the Eurostat data $(2017,1,2)$, an ageing index was calculated. The ageing index was highest in DelDunantul and Del-Alfold regions (Hungary) in 2017. For 100 people aged $0-14$, there were 145 people in postproductive age. The lowest level of ageing index was in the Eastern Slovakia region. The Median age of population was highest in the Del-Dunantul region (44.1) and lowest in Eastern Slovakia region (37.6) in 2017.

\section{Efficiency Score and RCI Assessment}

Technical efficiency score in CCR and BCC models was calculated from 2014 input and output values in the EMS program. The values of technical efficiency score in CCR and BCC models are listed in Table 2.

Out of 35 NUTS2 regions, 5 regions were efficient in CCR model - Severozapad (Northwest, CR), Zachodniopomorskie, Lubuskie and Slaskie regions in Poland, and Bratislava region as the only in Slovakia. Surprisingly, three regions surrounding capital cities were not efficient. Interestingly enough, no Hungarian regions were efficient.

Ten regions were efficient in $\mathrm{BCC}$ model - the region of Prague and Severozapad (Northwest, CR), NyugatDunantul, Del-Dunantul, Eszak-Magyarorszag in Hungary, Slaskie, Zachodniopomorskie, Lubuskie and WarminskoMazurskie in Poland, and Bratislava region in Slovakia.

Table 2

Efficiency Score in BCC and CCR Models and RCI in NUTS2 Regions in V4 Countries

\begin{tabular}{|c|c|c|c|}
\hline Regions & CCR & BCC & RCI \\
\hline Prague & 0.97 & 1.00 & 0.21 \\
\hline Stredni Cechy (Central Bohemia) & 0.61 & 0.84 & 0.21 \\
\hline Jihozapad (Southwest) & 0.68 & 0.87 & -0.33 \\
\hline Severozapad (Northwest) & 1.00 & 1.00 & -0.45 \\
\hline Severovychod (Northeast) & 0.68 & 0.85 & -0.30 \\
\hline Jihovychod (Southeast) & 0.51 & 0.86 & -0.34 \\
\hline Stredni Morava (Central Moravia) & 0.70 & 0.89 & -0.44 \\
\hline Moravskoslezsko (Moravia-Silesia) & 0.77 & 0.92 & -0.41 \\
\hline Kozep-Magyarorszag (NUTS 2013) & 0.79 & 0.94 & -0.15 \\
\hline Kozep-Dunantul & 0.77 & 0.93 & -0.57 \\
\hline Nyugat-Dunantul & 0.99 & 1.00 & -0.54 \\
\hline Del-Dunantul & 0.77 & 1.00 & -0.79 \\
\hline Eszak-Magyarorszag & 0.71 & 1.00 & -0.78 \\
\hline Eszak-Alfold & 0.63 & 0.97 & -0.88 \\
\hline Del-Alfold & 0.66 & 0.94 & -0.79 \\
\hline Lódzkie (NUTS 2013) & 0.85 & 0.90 & -0.58 \\
\hline Mazowieckie (NUTS 2013) & 0.81 & 0.91 & -0.18 \\
\hline Malopolskie & 0.68 & 0.93 & -0.47 \\
\hline Slaskie & 1.00 & 1.00 & -0.41 \\
\hline Lubelskie (NUTS 2013) & 0.64 & 0.91 & -0.67 \\
\hline Podkarpackie (NUTS 2013) & 0.63 & 0.99 & -0.74 \\
\hline Swietokrzyskie (NUTS 2013) & 0.83 & 0.94 & -0.73 \\
\hline Podlaskie (NUTS 2013) & 0.73 & 0.90 & -0.73 \\
\hline Wielkopolskie & 0.96 & 0.98 & -0.73 \\
\hline Zachodniopomorskie & 1.00 & 1.00 & -0.71 \\
\hline Lubuskie & 1.00 & 1.00 & -0.70 \\
\hline Dolnoslaskie & 0.98 & 0.99 & -0.54 \\
\hline Opolskie & 0.91 & 0.98 & -0.58 \\
\hline Kujawsko-Pomorskie & 0.91 & 0.97 & -0.74 \\
\hline Warminsko-Mazurskie & 0.89 & 1.00 & -0.87 \\
\hline Pomorskie & 0.79 & 0.94 & -0.58 \\
\hline Bratislava region & 1.00 & 1.00 & 0.38 \\
\hline Zapadne Slovensko (Western Slovakia) & 0.95 & 0.96 & -0.56 \\
\hline Stredne Slovensko (Central Slovakia) & 0.84 & 0.98 & -0.75 \\
\hline Vychodne Slovensko (Eastern Slovakia) & 0.84 & 0.995 & -0.87 \\
\hline
\end{tabular}

$$
\text { Source of RCI is Eurostat }
$$

The highest arithmetic mean of technical efficiency score in both CCR and BCC models, as measured by the regional efficiency scores, was in Slovakia. The lowest average technical efficiency score in both CCR and BCC models was in the Czech Republic. Arithmetic means of efficiency score and the share of efficient regions relative to the number of regions in the countries under analysis are given in Table 3. 
The Share of Efficient Regions relative to the Number of Regions in the Countries Under Analysis and Arithmetic Means of Efficiency Score

\begin{tabular}{|c|c|c|c|c|c|}
\hline & $\begin{array}{c}\text { The } \\
\text { share of } \\
\text { efficient } \\
\text { regions } \\
\text { in CCR } \\
\text { model } \\
\end{array}$ & $\begin{array}{c}\text { Arithmetic } \\
\text { mean of } \\
\text { efficiency } \\
\text { score in } \\
\text { CCR } \\
\text { model } \\
\end{array}$ & The share of efficient regions in BCC model & $\begin{array}{l}\text { Arithmetic mean of efficiency } \\
\text { score in BCC model }\end{array}$ & $\begin{array}{l}\text { Arithmetic mean of } \\
\text { RCI value }\end{array}$ \\
\hline $\mathrm{CR}$ & $\begin{array}{c}1 / 8 \\
12.5 \% \\
\end{array}$ & 0.7400 & $2 / 8 \quad 25 \%$ & 0.9038 & -0.23 \\
\hline $\mathrm{HU}$ & $\begin{array}{l}0 / 7 \\
0 \%\end{array}$ & 0.7600 & $3 / 742.9 \%$ & 0.9686 & -0.64 \\
\hline PL & $\begin{array}{c}3 / 16 \\
18.8 \%\end{array}$ & 0.8506 & $4 / 1625 \%$ & 0.9588 & -0.62 \\
\hline SR & $\begin{array}{c}1 / 4 \\
25 \%\end{array}$ & 0.9075 & $1 / 4 \quad 25 \%$ & 0.9783 & -0.45 \\
\hline
\end{tabular}

To compare the efficient regions to one another, superefficiency score in EMS program was calculated. Superefficiency score values are given in Table 4.

The Bratislava region reached the highest superefficiency score in both CCR and BCC models. In BCC model, the region of Prague had a very high super-efficiency score. The lowest super-efficiency score in both models was reached by the Polish region of Slaskie.

The Super-Efficiency Score in \%

\begin{tabular}{|l|c|c|c|c|c|}
\hline & CCR & & BCC & BCC \\
\hline Severozapad (Northwest) & 122.74 & Region of Prague & high & Slaskie & 103.14 \\
\hline Slaskie & 102.71 & $\begin{array}{c}\text { Severozapad } \\
\text { (Northwest) }\end{array}$ & 126.01 & Zachodnio-pomorskie & 213.83 \\
\hline Zachodnio-pomorskie & 115.34 & Nyugat-Dunantul & 105.50 & Lubuskie & 163.57 \\
\hline Lubuskie & 156.93 & Del-Dunantul & 106.08 & Warminsko-Mazurskie & 105.94 \\
\hline Bratislava region & 202.19 & Eszak-Magyarorszag & 103.65 & Bratislava region & high \\
\hline
\end{tabular}

\section{The Relationship between Efficiency Score and RCI}

Table 2 shows RCI values. Higher RCI values mean a more positive regional competitiveness assessment. As seen from Table 2, the highest RCI values were reached in the Bratislava region. The best values were achieved in the innovation group. The regions of Prague and Stredni Cechy (Central Bohemia) ranked $2^{\text {nd }}$. These regions also have the best results in the innovation group. The poorest results were found in the regions of Eszak-Alfold (Hungary), Warminsko-Mazurskie (Poland) and Eastern Slovakia. The largest arithmetic mean of RCI values calculated from RCI model was found in the Czech Republic. The lowest arithmetic mean of RCI values was reached by Hungarian regions.

Next, the relationship between the two scores was examined. Tobit regression was used to find the relationship between technical efficiency scale and RCI.

Matrixer software was utilised to analyse the relationship between the efficiency score and the RCI by means of Tobit model. Dependent variable in regression was the efficiency score $\theta$ and the independent variable $S P$ was RCI.

Thus, the following relationship applies to the $\mathrm{j}^{\text {th }}$ regions $\theta_{j}=\beta_{0}+\beta_{1} S P_{j}+\varepsilon_{j} \varepsilon_{j} \sim N\left(0, \sigma^{2}\right)$.

The Tobit model parameters are shown in Table 5 .
Table 5

The Tobit Model with a Dependent Variable of Efficiency Score in CCR Model and the Independent Variable RCI

\begin{tabular}{|l|c|}
\hline & Common market \\
\hline Constant $\beta 0$ & 0.8255 \\
\hline Coefficient $\beta 1$ & 0.0227 \\
\hline Coefficient of determination (\%) & 0.2511 \\
\hline
\end{tabular}

Table 6

The Tobit Model with the Dependent Variable Efficiency Score in BCC Model and the Independent Variable RCI

\begin{tabular}{|l|c|}
\hline & Common market \\
\hline Constant $\beta_{0}$ & 0.9256 \\
\hline Coefficient $\beta_{1}$ & -0.0490 \\
\hline Coefficient of determination (\%) & 9.2754 \\
\hline
\end{tabular}

The determination coefficient in Tobit model with an independent variable of efficiency score in CCR model was only $0.2511 \%$ and the correlation coefficient only 0.0501 . The determination coefficient in Tobit regression with an independent variable of efficiency score in BCC model was only $9.2754 \%$ and the correlation coefficient was 0.3046 . Both techniques used to interpret regional competitiveness found values with a weak correlation. The correlation coefficient reached almost 0 in CCR model. From this analysis, it is not possible to conclude whether there is direct or indirect correlation between technical efficiency scale 
and RCI. In the case of BCC model, we can speak of a weak positive correlation.

There are both advantages and disadvantages to the methods used to assess competitiveness. The efficiency score has the advantage of expressing the efficiency of multiple input transformation into multiple outputs. It is a relative measure - it depends on the values of all the other objects. However, the choice of inputs and outputs is not unambiguous. At the same time, the number of inputs and outputs depends on the number of regions analysed. RCI takes into account 11 factors being classified into 3 groups which can be analysed even with fewer numbers of analysed regions. RCI, however, does not reflect the transformation of inputs into outputs.

If the arithmetic mean of efficiency score being calculated from the values in individual regions is chosen in the analysis as a criterion for the country competitiveness, the Czech Republic can be viewed as the most competitive country. This argument is not in contradiction with the conclusion stated by Stanickova and Melecky (2012). The Slovak Republic, however, could not be ranked second. The authors' conclusion that Poland and Hungary appear to be less effective than the Czech Republic and Slovakia was not confirmed. It is worth mentioning that the Bratislava region appears to be currently the most competitive region in V4 in both approaches.

\section{Conclusion}

In the introductory section, several methods and procedures on assessing regional competitiveness were described. In addition, various systems of indicators were specified to identify factors and methods that would help reduce the gap between developed and less advanced regions. Moreover, it was attempted to offer both theory and practice a non-traditional approach to evaluating regional efficiency and competitiveness. DEA models are among the less investigated and discussed methods in measuring regional competitiveness.

In practice, regions (as territorial units) are making great efforts to achieve competitiveness. Thus, the decisions made by their governments must be efficient, correct and timely.

The primary objective of the paper was to contribute to the body of knowledge on regional competitiveness disparities in the regions of the V4 countries. In the paper, two secondary objectives were set. The first objective was to identify the most competitive regions in the Visegrad Group. The second objective was to find whether there is a correlation between the two approaches chosen. Moreover, it was attempted to offer both theory and practice a nontraditional approach to evaluating regional efficiency and competitiveness. DEA models were employed to show what options there are for measuring regional efficiency and interpreting research results.

There were five efficient regions at NUTS 2 level in CCR model - Severozapad (Northwest), Zachodniopomorskie, Lubuskie, Slaskie and Bratislava region. No Hungarian regions were found to be efficient. In BCC model, ten regions were efficient - the region of Praha, Severozapad (Northwest), Nyugat-Dunantul, Del-Dunantul, EszakMagyarorszag, Slaskie, Zachodniopomorskie, Lubuskie and Warminsko-Mazurskie and Bratislava region. The Bratislava region was efficient in both models and achieved the highest super-efficiency score in both the CCR and BCC model. At the same time, the Bratislava region had the highest RCI value. Both techniques of expressing regional competitiveness found values with a weak correlation.

By using these methods it is possible to identify which regions are the most and least competitive. The most competitive regions can serve as the models for the less competitive ones. In practice, the regions need to know how to modify the values of their indicators to catch up with the most competitive ones. This is not an easy task as there are several indicators taken into consideration when assessing competitiveness. RCI method does not say how the values of indicators are to be modified. CCR and BCC models, however, do. These radial input-orientated models enable to express the need of modifying the basic inputs. This is why they make a difference.

The research, however, has some limitations. The assessment and comparison of competitiveness covered only the period of one year. To generalize the conclusions, it would be necessary to assess the competitiveness over the time series of several years. A major limitation is that the selected macro indicators used in CCR and BCC models cover less information than the RCI index under comparison taken from 11 pillars.

\section{Acknowledgements}

This paper is the part of the project VEGA 1/0233/16

\section{References}

Annoni, P., \& Dijkstra L. (2013). EU Regional Competitiveness Index RCI 2013. Luxembourg: Publications Office of the European Union, 2013. p. 183. https://doi.org/10.2788/61698

Andreev, A.V., Borisova, L. M., \& Pluchevskaya, E. V. (2008). Bases of Regional Economy, 334(2), pp. $141-145$.

Audretsch, D. B. \& Pena-Legazkue, I. (2012). Entrepreneurial Activity and Regional Competitiveness: an Introduction to the Special Issue. Small Business Economics, 39(3), pp. 531-537. https://doi.org/10.1007/s11187-011-9328-5

Bauler, T. (2002). Concept, Application and Validation-Efficiency of an "environmental system", Indicators for sustainable development in an inter-regional context, Brussels, 2002.

Boldea, M., Parean, M. M., \& Otil, M. (2012). Regional Disparity Analysis: The Case of Romania. In Journal of East. Europe Research in Business and Economics, Retrieved from: http://www.ibimapublishing.com/journals/ JIEBS/jiebs.html, 2012. https://doi.org/10.5171/2012.599140 
Dachin, A. (2008). Rural Development - a Basic Condition for Narrowing Regional Disparities in Romania. Romanian Journal of Reg. Science, 2(2), pp. 106-117.

Dijkstra, L., Annoni, P. \& Kozovska, K. (2011). A New Regional Competitiveness Index: Theory, Methods and Findings. European Union Regional Policy Working Papers, 02/2011.

Eurostat $(2014,2)$. Retrieved from: lfst_r_lfe2emprt, [on-line] [cit.: 2018-03-15].

Eurostat (2014, 1). Retrieved from: hrst_st_rcat, [on-line] [cit.: 2018-03-15].

Eurostat (2014, 3). Retrieved from: rd_e_gerdreg, [on-line] [cit.: 2018-03-19].

Eurostat $(2014,4)$. Retrieved from: nama_10r_2gdp, [on-line] [cit.: 2018-03-02]. http://appsso.eurostat.ec.europa.eu/nui/show.do?dataset=nama_10r_2gdp\&lang=en

Eurostat (2014, 5). Retrieved from: http://appsso.eurostat.ec.europa.eu/nui/show.do

Eurostat $(2017,1)$. Retrieved from: demo_r_pjanind2, [on-line] [cit.: 2018-07-11]

Eurostat $(2017,2)$. Retrieved from: demo_r_d2jan, [on-line] [cit.: 2018-07-11]

Eurostat Regional Yearbook (2014). Retrieved from: edition, http://ec.europa.eu/eurostat/documents/3217494/5785 629/KS-HA-14-001-EN.PDF, [on-line] [cit.: 2018-03-15].

European Commission (2013). EU Regional Competitiveness Index. RCI 2013 Retrieved from: http://ec.europa.eu/regional _policy/sources/docgener/studies/pdf/6th_report/rci_2013_report_final.pdf

Gabdrakhmanov, N. K., \& Rozhko, M. V. (2014). Positioning of Volga Federal District Regions by Demographic Situation Index. World Applied Sciences Journal, 30(6), pp. 792-795.

Goschin, Z., Constantin, D. L., Roman, M., \& Ileanu, B. (2008). The Current State and Dynamics of Regional Disparities in Romania, Romanian J. of Reg. Science, 2(2), pp. 80-105.

Granberg, A. G., Busygina, I. M., \& Vvedensky, V. G. (2000). Regional Development: the Experience of Russia and the European Union. ZAO Publishing House Economics, 435(4), 335-338.

Guneş, N., \& Yilmaz, A. (2016). Determinants of Efficiencies in Turkish Banking Sector (Tobit Analysis). International Journal of Economics and Finance, 8(2), pp. 215-225. https://doi.org/10.5539/ijef.v8n2p215

Ivanova, E., Kordos, M., \& Habanik, J. (2015). The Competitiveness of V-4 Countries within the European Union, Actual Problems of Economics, 167(5), pp. 39-49.

Ivanova, E., \& Masarova, J. (2017). Comparison of Selected Indicators of Competitiveness of V4 Countries. In: Knowledge for Market Use 2017: People in Economics - Decisions, Behavior and Normative Models: International scientific conference proceedings. Olomouc: Palacky University, pp.1035-1045.

Jablonsky, J., \& Dlouhy, M. (2004). Models of Efficiency Evaluation of Production Units. Praha: Professional Publishing.

Komarova, M. A. (2007). About the Criteria of the Region's Competitiveness. Ways and Mechanisms of Ensuring the Competitiveness of the Russian Regions. Russia, Saratov: Povolzhskaya Academy of Public Service. P. A. Stolypin.

Kordos, M. 2016. Creative Industry Within the European Regional Policy - Effects and Benefits. In: Knowledge for Market Use 2016: Our Interconnected and Divided World, pp.199-207.

Lengyel, I., \& Rechnitzer,J. (2013). The Competitiveness of Regions in the Central European Transition Countries. The Macrotheme Review 2(4), pp. 106-121.

Mereuta, C., Albu, L.L., Iordan, M. \& Chilian, M.N. (2007). A Model to Evaluate the Regional Competitiveness of the EU Regios, Romanian Journal of Economic Forecasting. 3/2007. Institute of Economic Forecasting, pp.81-102.

Malakauskaite, A. \& Navickas, V. (2011). Contribution of Clusters to the Competitiveness of Companies: Revelation and Evaluation. Inzinerine Ekonomika-Engineering Economics, 22(1), pp. 50-57. https://doi.org/10.5755/j01.ee.22.1.218

Malakauskaite, A., \& Navickas, V. (2010). Relation between the Level of Clusterization and Tourism Sector Competitiveness. Inzinerine Ekonomika-Engineering Economics, 66(1), 60-67.

Mashokhida, A., Khabibovich, A. A., Palka, P., \& Shakhlo, R. (2018). Journal of Competitiveness, 10(1), pp. 73-88. https://doi.org/10.7441/joc.2018.01.05

OECD (2018). Regional competitiveness. Retrieved from: http://www.oecd.org/cfe/regional-policy/regionalcompeti tiveness.html

Poot, J. (2008). Demographic Change and Regional Competitiveness: The Effects of Imigration and Ageing. International Journal of Foresight and Innovation Policy, 4(1-2), pp. 129-145. https://doi.org/10.1504/IJFIP.2008.016910

Stanickova, M., \& Melecky, M. (2012). Competitiveness Evaluation of Visegrad Four Countries by CCR Input Oriented Model of Data Envelopment Analysis. Retrieved from: file://D:/Competitivenes/Stanickova\%20Melecky\%20CR.pdf 
Eva Koisova, Eva Grmanova, Katarina Skrovankova, Julia Kostrova. Competitiveness of Regions in the Visegrad...

Stanickova, M., \& Skokan, K. (2012). Evaluation of the EU Member States Efficiency by Data Envelopment Analysis Method. International Journal of Mathematical Models and Methods in Applied Sciences, 2(6), pp. 349-357.

Torok, I. (2018). Competitiveness of Romanian Regions in the Spatial Structure of the EU. World Multidisciplinary Earth Sciences Symposium (WMESS 2017). IOP Conf. Series: Earth and Environmental Science, 95(2017) 052013. doi:10.1088/1755-1315/95/5/052013.

Viturka, M. (2007). Konkurecieschopnost' regionu a možnosti jejiho hodnoceni. Politicka ekonomie, 5., pp.637-658. https://doi.org/10.18267/j.polek.617

Zitek, V., \& Klimova, V. (2015). The Competitiveness Index of Czech Regions. Acta Universitatis Agriculturae Et Silviculturae Mendelianae Brunensis, 63(2), pp. 693-701http://dx.doi.org/10.11118/actaun201563020693.

The article has been reviewed.

Received in October 2018; accepted in April 2019. 